\title{
MPs challenge rejection of genetics panel
}

London. A sharp conflict of views has arisen between the British government and a key group of Members of Parliament over the extent to which the government should take responsibility for mitigating the potentially harmful effects of new discoveries in human genetics and their social applications.

Last week, the government announced details of a new Advisory Committee on Genetic Testing - thought to be the first committee of its type in the world - which will have responsibility to ensure that genetic screening tests "are supplied safely and used ethically".

At the same time, however, it rejected as "unnecessary" a proposal from the House of Commons' Science and Technology Committee, made in a report issued last July after eight months of hearings, to establish a national Human Genetics Commission to maintain a strategic overview of the development of the science and the social and ethical issues it is likely to raise in the future (see Nature 376, 202; 1995).

In its response to the report, the government has said that it feels the existing network of "more targeted advisory bodies" is already "largely effective" in achieving this task. But members of the committee disagree and, in a highly unusual move, are now planning to hold a further hearing at which those previously called to give evidence will be asked to comment on the government's response.

"Our concern is that without an overview of how genetics is developing, we could be faced with a series of ad hoc decisions engineered by successive crises," says Spencer Batiste (Conservative, Elmet). "We need a flexible framework that can take a serious and measured overview of what is going on; by rejecting that proposition, the government has made a number of us on the committee unhappy."

The government's main reaction to the select committee's report came from Ian Taylor, the science and technology minister, in answer to a parliamentary question. Taylor said that he welcomed the report's support for the Human Genome Project, stressing that genetics provided "major opportunities for partnership between industry, the science base and government".

Taylor also said that the government recognized "the sensitivities which can apply to the application of genetics in healthcare and other fields". But the government's written response indicates that it is reluctant to take extra steps to regulate such activities - for example, specifically rejecting the proposal that it should introduce legislation covering the use of genetic information by the insurance industry.

Unsurprisingly, this response met with relief within the industry. "I think that it is a sensible and balanced view by the govern- ment," says Paul Smee, of the Association of British Insurers, which had earlier been given one year by the science committee to draw up a code of conduct.

But the government's response has come under fire from various groups which have been campaigning for more action to prevent the misuse of genetics in fields such

IMAGE
UNAVAILABLE
FOR COPYRIGHT
REASONS

Genetic identity: parliamentarians want a commission to monitor ethical issues.

as insurance and employment, and feel that government officials, while listening to their case, have ignored their conclusions.

"I am fairly dismayed," says David Shapiro, executive secretary of the Nuffield Council on Bioethics, which last year produced a report on genetic screening referred to approvingly in the government'sresponse. "Our minimum recommendation was that the implications of what was happening in the fields of insurance and employment should come within the remit of an advisory committee. It is open to government to reject that view, but not to wave around the fact that they have taken our report into consideration in drawing their conclusions."

The Genetics Interest Group, a pressure group which has been campaigning vigorously to defend the interests of those it considers vulnerable to 'genetic discrimination',

was even more outspoken in its criticism. Members of the group describe the report as a "missed opportunity" that failed to recognize the importance of transdepartmental links on genetics-related issues.

Kay Davies, professor of genetics at the University of Oxford, and chair of a committee that produced a report for the Office of $\vec{a}$ Science and Technology two years ago on human genome research, arguing the need for a broad, strategic approach embracing both the interests of the public and the private sector, expresses similar concern. "If we do not get the infrastructure [for developing the applications of genetics] right now, the situation is going to become dreadful once we get on the issues raised, for example, by the ability to screen for a predisposition to multifactorial diseases," says Davies.

For the present, however, the only new government activity will be to support the work of the advisory committee on genetic screening. Announced in parallel with Taylor's statement by John Horam, the Parliamentary Secretary for Health, the committee will be chaired by the Reverend John Polkinghorne, president of Queen's College, Cambridge, and a former physicist who headed an earlier inquiry into the use of fetal tissue in research.

The advisory committee will be responsible for monitoring the use - or potential use - of genetic screening tests within clinical practice, and as they are likely to be used through direct sale to the public. According to the Department of Health, the committee "will need to be reassured" on topics such as the implications of screening tests.

So far, government officials say they remain convinced that the various other issues raised by genetics can be adequately covered by similar existing advisory committees, as well as statutory bodies such as the Health and Safety Executive. But the members of the select committee are not expected to leave the rejection of their proposals unanswered.

David Dickson

\section{Charity head faces resignation calls}

Paris. Jacques Crozemarie, chairman of France's biggest charity, L'Association pour la Recherche sur le Cancer (ARC), is likely to be ousted at an emergency meeting next week of the charity's executive board.

The meeting has been convened by the six-man working group set up earlier this month to study the claims of serious financial mismanagement at the charity made in a leaked report from the Cour des Comptes - the national audit commission (see Nature 379, 103; 1996). Their action was prompted in particular by Crozemarie's sacking last week of Thierry Hercend, who had been managing director of ARC for just four months, apparently on the grounds that he was being too cooperative with the working group.

Crozemarie himself announced during a radio interview last week that he would resign. Later the same day, however, he issued a statement saying that he would not resign until the full light was thrown on the "attacks" on ARC.

But the working group, which is made up of members of ARC's executive board, has itself been accused of trying belatedly to distance itself from Crozemarie: the board has endorsed ARC's practices in the past, and defended the charity against similar allegations to those made in the audit.

Declan Butler 